\title{
Does Air Pollution Influence COVID-19 Outbreaks?
}

\author{
Daniele Contini $^{1, *(D)}$ and Francesca Costabile ${ }^{2}$ (D) \\ 1 Istituto di Scienze dell'Atmosfera e del Clima, ISAC-CNR, Str. Prv. Lecce-Monteroni km 1.2, \\ 73100 Lecce, Italy \\ 2 Istituto di Scienze dell'Atmosfera e del Clima, ISAC-CNR, Via Fosso del Cavaliere 1, 00133 Rome, Italy; \\ f.costabile@isac.cnr.it \\ * Correspondence: d.contini@isac.cnr.it
}

Received: 9 April 2020; Accepted: 10 April 2020; Published: 13 April 2020

Severe acute respiratory syndrome coronavirus 2 (SARS-CoV-2) [1] is the pathogen of the COVID-19 disease. COVID-19 was initially reported in December 2019 in a small cluster in Wuhan (Hubei Province, China), it then successively spread all over the world. The World Health Organization (WHO) declared COVID-19 a Public Health Emergency of International Concern. At the beginning of April 2020, it clearly appears that there are remarkable differences in terms of the rate of spread and mortality in the outbreaks of COVID-19 in different countries of the world. These differences have raised important questions related to the influence of atmospheric factors, such as atmospheric pollution, on the spread of COVID-19 (why it is so transmissible) and on its mortality rate (why it is so different around the world and, even, in different regions of the same country). The complexity of the topic is far from being solved, with several urgent aspects still requiring further investigation. Consequently, these questions are open challenges for current research initiatives. Here, we aim to address two specific aspects in an attempt to highlight critical gaps relevant for future.

What is the influence of atmospheric aerosol, and more generally, air pollution, in eliciting indirect systemic effects (linked to pro-inflammation and oxidation mechanisms of the lungs, and immunological alteration processes) increasing the vulnerability of the population to COVID-19?

Prolonged exposure to air pollution has been linked to acute respiratory inflammation, asthma attack, and death from cardiorespiratory diseases in various studies [2-6]. Fine particulate matter (particles with aerodynamic diameters less than $2.5 \mu \mathrm{m}, \mathrm{PM}_{2.5}$ ) is considered one of the leading environmental health risk factors, causing several million deaths per year globally $[7,8]$. Atmospheric aerosol can be a co-factor of indirect systemic effects within the human body associated with pro-inflammation and oxidation mechanisms in the lungs and extrapulmonary organs, as well as with immune system alteration processes. Although confounding effects could be present (such as, for example, age of exposed people and gender), the possibility of a detrimental effect of air pollution on the prognosis of patients affected by COVID-19 is plausible and deserves further investigation. A 2003 study [9] reported an ecological analysis of the previous coronavirus SARS in China and found that patients in regions with moderated air pollution levels (air pollution index, API) were more likely to die than those in regions with low APIs. A 2017 study [10] investigated the main factors influencing the mortality of the 2009 influenza $\mathrm{A}\left(\mathrm{H}_{1} \mathrm{~N}_{1}\right)$ pdm09 pandemic, which presented prominent regional variability. The study identified 124 publications and analyzed 27 possible risk factors, including $\mathrm{PM}_{10}$ concentrations. Results showed that $\mathrm{PM}_{10}$ explained only $4 \%$ of the mean between country variance and that other factors had larger or comparable weights: the age structure $(40 \%)$, latitude $(8 \%)$, influenza A and B viruses circulating during the pandemic (3-8\%), and prevalence of other infections (4-6\%).

An important point deserving further attention is the possible influence of the physicochemical properties of aerosol particles involved in the generation of inflammation and immunotoxicity within different targets of the human body. The toxicological mechanisms associated with aerosols potentially eliciting adverse cellular effects, such as cytotoxicity through oxidative stress, 
oxygen-free radical-generating activity, DNA oxidative damage, mutagenicity, and the stimulation of pro-inflammatory responses, are currently unclear. Indeed, particle size matters, and it is important to consider the role of ultrafine particles (particles with aerodynamic diameters smaller than $100 \mathrm{~nm}$ ) on health outcomes [11,12]. The role of chemical composition influences ecotoxicity, cytotoxicity, and genotoxicity in different ways, so that different biological outcomes are expected even in cases of similar number and mass concentrations [13]. Although the interpretation of data is still uncertain, the possibility that exposure to air pollutants may contribute to increasing the vulnerability of a population to COVID-19 is plausible. However, caution should be used in translating high values of conventional aerosol metrics, such as $\mathrm{PM}_{2.5}$ and $\mathrm{PM}_{10}$ concentrations without chemical, physical, and biological analysis, to an increase in vulnerability or to a direct explanation of the differences in mortality observed in different countries.

Finally, it should be noted that the role of pollution was suggested to partially explain the differences in mortality observed in northern Italy compared to other regions of Italy, based on information that was available as of mid-March [14]. It must be said that the current data on mortality (and contagions) could be affected by relevant uncertainty due to the different strategies used for counting deaths related to COVID-19 and infected people. Furthermore, recent outbreaks of COVID-19 also took place in areas (Spain, the USA, the UK, France) characterized by very different pollution levels compared to northern Italy in winter (and also compared to Wuhan in China); no significant outbreaks (up to now) have been observed, fortunately, in very highly populated and polluted cities in India. This suggests that several variables are potentially involved in the spread of COVID-19 and in the current evaluation of its mortality, such as the age distribution of a population, population density, social habits, the restrictive measures applied, and meteorological conditions. All of these factors should be considered in further studies, together with atmospheric pollution, to correctly estimate the importance (weights) of each of the factors in COVID-19 spread, as recently suggested by the Italian Aerosol Society [15].

Airborne transmission of SARS-CoV-2. Is it a plausible mechanism? If so, what is the probability of occurrence in outdoor and indoor environments?

When infected people are detected, there is no way to ascertain with certainty how they were infected. The epidemiological approach to carefully track who came into contact with an infected person does not provide conclusive information on how the virus was effectively transferred. There are different possible transmission routes of the respiratory virus among humans [16] and it is difficult to estimate the relative contribution of each route. These include direct contact between infected and susceptible individuals or indirect contact mediated by a "fomite" (i.e., an object or surface that has been contaminated with the virus). Airborne transmission may occur in two distinct modes not requiring direct contact. The first mode is via large ( $>5 \mu \mathrm{m}$ in diameter) virus-laden droplets released by infected individuals via a cough or sneeze; the second mode is when a susceptible individual inhales small virus-laden aerosols released during respiration or vocalism [17] or the residual solid component after the evaporation of droplets [18]. Large droplets, emitted in a cough or sneeze, are quickly stopped by the resistance of air and removed by dry deposition, mainly through gravitational settling, generally at a distance smaller than 1-1.5 m from the emission. The smaller virus-laden particles $(<5 \mu \mathrm{m}$ in diameter) related to the respiratory emissions of infected individuals could remain in the air for hours and could be transported and dispersed by winds and turbulent eddies. Therefore, it is plausible that this mechanism could contribute to the contagion, however, knowledge of several parameters is necessary to evaluate the effective probability of contagion and its weight compared to other transmission routes (direct contact, via fomites, and transmission via large droplets). Other important factors include the effective concentration and the size distribution of virus-laden aerosols in air, the chemical and biological composition of the bioaerosol, the lifetime of the virus in the aerosol, and the minimum amount of viable virus needed to be inhaled to produce infection. Further research is required to determine the characteristics of these last parameters. Recent works [19,20] demonstrated that aerosolized SARS-CoV-2 remains viable in the air with a half-life in the order of $1 \mathrm{~h}$ in a laboratory 
controlled environment, but the half-life could be different in outdoor environments in relation to meteorological conditions (temperature, relative humidity, ultraviolet radiation) that could degrade the virus [21,22]. In considering outdoor environments, Liu et al. [23] collected aerosol samples in public areas in Wuhan in February 2020 and found no detectable concentration of SARS-CoV-2 $\left(<3\right.$ copies $\left./ \mathrm{m}^{3}\right)$ in all but two crowded sites. This is a very low concentration compared to the typical concentration of atmospheric particles, which generally varies between $100,000,000$ particles $/ \mathrm{m}^{3}$ in remote uncontaminated areas (high mountains, Antarctica) and 100,000,000,000 particles $/ \mathrm{m}^{3}$ in highly polluted urban areas [24]. Considering the typical volume of air involved in respiration, in the range of $0.5-1.5 \mathrm{~m}^{3}$ /hour, the probability of inhalation of airborne viable virus in outdoor environments is very low.

The situation is different in indoor environments, for example, hospitals, in which there are several infected individuals in restricted spaces and, eventually, poor air exchange and/or mechanical ventilation/conditioning. In these cases, the source is more intense, the dispersion due to turbulence and consequent dilution is more limited in confined spaces, and meteorological environmental conditions like temperature, relative humidity, and UV radiation are more stable, creating an environment that is more favorable to the survival of the virus. Indoor measurements showed widespread presence of viral RNA in the air in isolation rooms where patients with SARS-CoV-2 were receiving care [25]. This indicates that viral particles can be spread airborne in indoors via bioaerosols; however, the presence of an RNA sequence is not a clear signal of its viability. The authors reported that finding infectious virus has proved elusive and that further experiments are needed to determine viral activity in the collected samples. An analysis by Liu et al. [23] of aerosol samples in two hospitals in Wuhan showed the highest concentrations in patient care areas (in toilet facilities about $19 \mathrm{copies} / \mathrm{m}^{3}$ ) and in medical staff areas in personal protective equipment removal rooms (18-42 copies $/ \mathrm{m}^{3}$ ). A fraction of these particles was in the fine size range $(0.2-1 \mu \mathrm{m})$, potentially able to to remain in the air for a longer time compared to coarse fractions, thus being more suitable for airborne transmission. Furthermore, in indoor environments, it could be relevant the deposition of these particles on surfaces representing an increased risk of transmission via fomites. Therefore, the risk of contagion via airborne virus-laden aerosols could be higher in specific indoor environments compared to outdoors. Additional research is necessary, both in indoor and outdoor environments, to investigate the aerosolization of SARS-CoV-2 during respiration and speech, the concentrations and size distribution of the virus in air for different conditions, as well as physico-chemical and biological properties, lifetime, and infectivity of the bioaerosol containing virus.

\section{Concluding Remarks}

SARS-CoV-2 is highly transmissible (with more than 1.3 million people infected in the world at the time of this writing) and lethal (more than 76,000 reported deaths at present). Exposure to air pollution could increase vulnerability and have detrimental effects on the prognosis of patients affected by the COVID-19. However, the relative weight of air pollution, compared to other confounders, is still to be determined.

Caution should be used in translating high values of conventional metrics, such as $\mathrm{PM}_{2.5}$ and $\mathrm{PM}_{10}$ concentrations, into a direct measure of vulnerability. Airborne transmission mediated by virus-laden aerosols emitted during expiration and speech is plausible in specific environments. Current knowledge indicates a low probability in outdoor environments and an increase in probability in specific indoor environments, like hospitals and areas where patients are quarantined. In these environments, it is advisable to mitigate the risk for vulnerable people via using periodic ventilation of environments, decontaminations of surfaces and air conditioning systems, and appropriate technologies for mechanical ventilation/conditioning in order to limit the circulation of virus-laden bioaerosols in air.

The stakes for the world are enormous, and the results of robust research studies are urgently needed in order to provide information that could help in developing strategies for facing the current pandemic as well as future pandemics. Our recommendations for future research focus 
on (but are not limited to) the investigation, both outdoors and indoors, of airborne transmission routes, lifetimes and dynamics, dosimetry and infection thresholds within the human body, and the physical/chemical/biological/toxicological/virological properties of virus-laden bioaerosol particles, with all of these factors properly adjusted for a wide number of potential confounders. This research should come from a multidisciplinary approach involving a strong collaboration between traditionally distinct disciplines of science, and in particular, virologists, epidemiologists, toxicologists, physicians, aerobiologists, aerosol scientists, and meteorologists.

Author Contributions: D.C. and F.C. contributed to conceptualization and writing. All authors have read and agreed to the published version of the manuscript.

Funding: This research received no external funding.

Acknowledgments: The authors wish to thank all the researchers of the Institute of Atmospheric Sciences and Climate of CNR (ISAC-CNR, www.isac.cnr.it) and the Steering Committee and members of the Italian Aerosol Society, www.iasaerosol.it) for the useful and extensive discussions that contributed to developing this manuscript.

Conflicts of Interest: The authors declare no conflicts of interest.

\section{References}

1. Lu, R.; Zhao, X.; Li, J.; Niu, P.; Yang, B.; Wu, H.; Wang, W.; Song, H.; Huang, B.; Zhu, N.; et al. Genomic characterisation and epidemiology of 2019 novel coronavirus: Implications for virus origins and receptor binding. Lancet 2020, 395, 565-574. [CrossRef]

2. Bates, D.; Baker-Anderson, M.; Sizto, R. Asthma attack periodicity: A study of hospital emergency visits in Vancouver. Environ. Res. 1990, 51, 51-70. [CrossRef]

3. Schwartz, J.; Dockery, D.W. Particulate Air Pollution and Daily Mortality in Steubenville, Ohio. Am. J. Epidemiology 1992, 135, 12-19. [CrossRef] [PubMed]

4. Dockery, D.W.; Pope, C.A. Acute respiratory effects of particulate air pollution. Annu. Rev. Public Health 1994, 15, 107-132. [CrossRef] [PubMed]

5. Schwartz, J.; Slater, D.; Larson, T.V.; Pierson, W.E.; Koenig, J.Q. Particulate Air Pollution and Hospital Emergency Room Visits for Asthma in Seattle. Am. Rev. Respir. Dis. 1993, 147, 826-831. [CrossRef] [PubMed]

6. World Health Organization. Ambient Air Pollution: A Global Assessment of Exposure and Burden of Disease; World Health Organization: Geneva, Switzerland, 2016; pp. 1-121. ISBN 9789241511353.

7. Lelieveld, J.; Evans, J.S.; Fnais, M.; Giannadaki, D.; Pozzer, A. The contribution of outdoor air pollution sources to premature mortality on a global scale. Nature 2015, 525, 367-371. [CrossRef] [PubMed]

8. Lelieveld, J.; Klingmueller, K.; Pozzer, A.; Pöschl, U.; Fnais, M.; Daiber, A.; Münzel, T. Cardiovascular disease burden from ambient air pollution in Europe reassessed using novel hazard ratio functions. Eur. Heart $J$. 2019, 40, 1590-1596. [CrossRef] [PubMed]

9. Cui, Y.; Zhang, Z.-F.; Froines, J.R.; Zhao, J.; Wang, H.; Yu, S.-Z.; Detels, R. Air pollution and case fatality of SARS in the People's Republic of China: An ecologic study. Environ. Health 2003, 2, 15. [CrossRef] [PubMed]

10. Morales, K.F.; Paget, J.; Spreeuwenberg, P. Possible explanations for why some countries were harder hit by the pandemic influenza virus in 2009-A global mortality impact modeling study. BMC Infect. Dis. 2017, 17, 642. [CrossRef] [PubMed]

11. Health Effects Institute. Understanding the Health Effects of Ambient Ultrafine Particles; HEI Perspectives 3; Health Effects Institute: Boston, MA, USA, 2013.

12. Costabile, F.; Alas, H.D.C.; Aufderheide, M.; Avino, P.; Amato, F.; Argentini, S.; Barnaba, F.; Berico, M.; Bernardoni, V.; Biondi, R.; et al. First Results of the "Carbonaceous Aerosol in Rome and Environs (CARE)" Experiment: Beyond Current Standards for $\mathrm{PM}_{10}$. Atmosphere 2017, 8, 249. [CrossRef]

13. Lionetto, M.G.; Guascito, M.R.; Caricato, R.; Giordano, M.; De Bartolomeo, A.; Romano, M.; Conte, M.; Dinoi, A.; Contini, D. Correlation of Oxidative Potential with Ecotoxicological and Cytotoxicological Potential of PM10 at an Urban Background Site in Italy. Atmosphere 2019, 10, 733. [CrossRef]

14. Conticini, E.; Frediani, B.; Caro, D. Can atmospheric pollution be considered a co-factor in extremely high level of SARS-CoV-2 lethality in Northern Italy? Environ. Pollut. 2020, 114465. [CrossRef] [PubMed] 
15. Italian Aerosol Society. Information on the Relationship between Air Pollution and the Spread of COVID-19. Available online: www.iasaerosol.it/attachments/article/96/Nota_Informativa_IAS_English.pdf (accessed on 8 April 2020).

16. Tellier, R.; Li, Y.; Cowling, B.J.; Tang, J.W. Recognition of aerosol transmission of infectious agents: A commentary. BMC Infect. Dis. 2019, 19, 101. [CrossRef] [PubMed]

17. Asadi, S.; Wexler, A.S.; Cappa, C.D.; Barreda, S.; Bouvier, N.M.; Ristenpart, W.D. Aerosol emission and superemission during human speech increase with voice loudness. Sci. Rep. 2019, 9, 2348. [CrossRef] [PubMed]

18. Asadi, S.; Bouvier, N.; Wexler, A.S.; Ristenpart, W.D. The coronavirus pandemic and aerosols: Does COVID-19 transmit via expiratory particles? Aerosol Sci. Technol. 2020, 1-4. [CrossRef]

19. Van Doremalen, N.; Bushmaker, T.; Morris, D.H.; Holbrook, M.G.; Gamble, A.; Williamson, B.N.; Tamin, A.; Harcourt, J.L.; Thornburg, N.J.; Gerber, S.I.; et al. Aerosol and Surface Stability of SARS-CoV-2 as Compared with SARS-CoV-1. N. Engl. J. Med. 2020, 1-3. [CrossRef] [PubMed]

20. Kampf, G.; Todt, D.; Pfaender, S.; Steinmann, E. Persistence of coronaviruses on inanimate surfaces and their inactivation with biocidal agents. J. Hosp. Infect. 2020, 104, 246-251. [CrossRef] [PubMed]

21. Casanova, L.M.; Jeon, S.; Rutala, W.A.; Weber, D.J.; Sobsey, M.D. Effects of Air Temperature and Relative Humidity on Coronavirus Survival on Surfaces. Appl. Environ. Microbiol. 2010, 76, 2712-2717. [CrossRef] [PubMed]

22. Walker, C.M.; Gwangpyo, K.O. Effect of Ultraviolet Germicidal Irradiation on Viral Aerosols. Environ. Sci. Technol. 2007, 41, 5460-5465. [CrossRef] [PubMed]

23. Liu, Y.; Ning, Z.; Chen, Y.; Guo, M.; Liu, Y.; Gali, N.K.; Sun, L.; Duan, Y.; Cai, J.; Westerdahl, D.; et al. Aerodynamic Characteristics and RNA Concentration of SARS-CoV-2 Aerosol in Wuhan Hospitals during COVID-19 Outbreak. Available online: https://www.biorxiv.org/content/10.1101/2020.03.08.982637v1 (accessed on 8 April 2020).

24. Seinfeld, J.H.; Pandis, S.N. Atmospheric Chemistry and Physics: From Air Pollution to Climate Change; Wiley: New York, NY, USA, 2006.

25. Santarpia, J.L.; Rivera, D.N.; Herrera, V.; Morwitzer, M.J.; Creager, H.; Santarpia, G.W.; Crown, K.K.; Brett-Major, D.; Schnaubelt, E.; Broadhurst, M.J.; et al. Transmission Potential of SARS-CoV-2 in Viral Shedding Observed at the University of Nebraska Medical Center. Available online: https://www.medrxiv. org/content/10.1101/2020.03.23.20039446v2 (accessed on 8 April 2020).

(C) 2020 by the authors. Licensee MDPI, Basel, Switzerland. This article is an open access article distributed under the terms and conditions of the Creative Commons Attribution (CC BY) license (http://creativecommons.org/licenses/by/4.0/). 